\title{
Industrial Labor Social Movement against the Issue of Neoliberalism (Case Study on the Movement and View of Trade Unions in Indonesia on the Global Issue of Neoliberalism)
}

\author{
Yudhi Rachman ${ }^{1}$, Bangun Sentosa $\mathrm{DH}^{2}$
}

\begin{abstract}
In December 1999, there was a large demonstration in Seattle, United States which triggered large demonstrations elsewhere to oppose neo-liberalism. An ideology of the capitalists in uniting a world economy free of national boundaries. Neoliberalism policies also occur in Indonesia, such as through privatization, the application of a flexible labor market or outsourcing

The problem discussed in this paper is how the trade union movement and response to the policy of neoliberalism theoretical studies in this study use Marx's Conflict Theory, Smelserian social movements and Gramsci's Hegemony. This research uses descriptive, qualitative type

The results showed that there were two types of trade unions that emerged after the reform, namely moderate trade unions and radical trade unions. The responses of these two types of trade unions differ in their response to the policy of neoliberalism. The first union prefers compromise while the radical trade union prefers confrontational methods. The emergence of labor awareness about the dangers of neoliberalism is a step forward when compared to the image of the previous labor movement. which only moves at the level of normative issues
\end{abstract}

Key words: Social Movements, Trade Unions, Neoliberal Policy

\section{INTRODUCTION}

In December 1999, there was a large demonstration in Seattle in the United States involving hundreds of thousands of people, then blew up hundreds of other large demonstrations in the other hemisphere, only to face the same enemy, neo-liberalism, an ideology that became the foundation of the capitalists in uniting world economy. From mass media campaigns and small and sporadic demonstrations, the anti-globalization movement has begun to adopt new tactics, blocking the course of

1. Yudhi Rachman, Department of Sociology, Faculty of Social and Political Sciences, Trunojoyo University Madura, email: yudhi.rachman@trunojoyo.ac.id

2. Bangun Sentosa DH, Department of Sociology, Faculty of Social and Political Sciences, Trunojoyo University Madura international meetings which they claim will be more miserable to the world.

In July 2000, the South Korean Trade Union repeatedly launched strikes and protests against the "tightening belts" policy advocated by the IMF. A month later the left movement in Brazil held a plebiscite about the IMF program in Brazil. More than 6 million people voted, and the majority said they refused. In September solidarity actions supporting the S-26 took place throughout the world, in South Africa, thousands of activists took to the streets in Durban, demonstrating in front of the US embassy in Cape Town and making a rally to the company's headquarters confronting it with violence and spray. pepper water on the faces of the activists.

In April 2000 a meeting of the Southern States took place in Havana, Cuba. Present there were the leaders of the Third World, including Abdurrachman Wachid as the President of Indonesia at that time. Fidel Castro as the host of the meeting gave a speech to represent the views of the oppressed people [1].

The biggest momentum of the anti-liberalization movement was a massive demonstration in Seattle, USA. In 1999, the demonstration in Seattle was not the beginning indeed, many actions with the same issue in various countries before, the superiority of Seattle action propaganda was launched at the momentum of the WTO session. The energy of resistance that began to spread then flowed to developed industrial countries, the center of the gathering of world rulers to determine policies that afflict the majority of the world's population. The aim is not to stop globalization itself, but rather to change principles and methods which on the one hand strengthen and enrich giant companies and on the other hand weaken the people of the world, and make them poorer. Therefore, the goal is not just one or two policies that are considered detrimental, but all institutions that design the system, especially the IMF, the World Bank and the WTO G-7 Countries and Transnational Enterprises

The people's movement against globalization projects is a general awareness that is currently rising, including in Indonesia. Various divestment/privatization policies such 
as those of Indosat, BCA sales at much lower prices compared to assets owned by PT. Semen Gresik, PT. Telkom, PT. KAI, PT. Bukit Assam and so on are not even half-hearted, until the end of 2003 the government had targeted the sale of around 20 state-owned companies, all of which were vital assets of the country such as PT. Indofarma, Perusahaan Gas Negara, BRI Angkasapura, Nusantara Bonded Zone and others[2].

For them this kind of step is natural. Moreover, basically the privatization program or the sale of state assets has been decided by the DPR / MPR as a cure for the crisis as agreed with the IMF and has been approved by the DPR. Not surprisingly then Laksamana Sukardi as Minister of BUMN dared to sue Amien Rais who accused Laksamana Sukardi of being a 'Foreign Imperialist Agent'. A funniest political farce in the history of Indonesian politics saw the populist attitude of the chairperson of the Indonesian People's Consultative Assembly who was seen washing his hands of a policy in which he was also involved.

Workers' resistance in fighting for their destiny continues to roll, including policies that are considered Pro Neoliberalism. As MayDay's warning on May 1, 2003, at least 56 unions from hundreds of companies joined in the May 1 Action Committee rallied in front of the Merdeka Palace demanding:

1. Making May 1 National Day.

2. Demand the revocation of UU-K and the cancellation of the PPHI Bill and the abolition of the contract work system 3. Demand improvement of the Wage system and reduce the price of basic necessities.

In the previous action to commemorate International Labor Day on May 1 2001, the demands included:

1. Write off foreign debt and reject the IMF

2. Unplug the Dual Function of ABRI

3. May 1 as a national holiday

In these demands it appears that the macroeconomic and political content is very thick, while structural and fundamental problems in the conditions of Indonesian workers themselves, such as wages, working hours, job guarantees, are still incomplete.

the emergence of workers' organizations after the fall of the Suharto Regime is one proof of the swift struggle, which has the same goal of promoting unity to fight oppression. Quite often many are responding narrowly to the birth of dozens of these labor elements. In fact, there are companies that prohibit the formation of trade unions without providing an alternative channel for their struggle. Perceptions about labor issues tend to be explored through narrow thinking. According to the Chairman of the Indonesian National Labor Struggle Front (FNPBI), Dita Indah Sari, there are two perceptions of trade unions. First, some consider that labor is merely a problem between workers and employers. Second, there is a wider view. Namely, labor is not only a problem between workers and employers, but between workers and employers, but between workers and the government, even with the international world. In this context labor issues are inevitably political in nature[3].

\section{FORMULATION OF THE PROBLEM}

Seeing this phenomenon, where the labor movement is actively involved in actions against anti-neoliberalism, the activity of the labor movement has increased both in terms of quality and quantity. The problem discussed in this paper is how the Workers' Movement and Response to social, political economy problems in the form of Neoliberalism that touches the lives of industrial workers in Indonesia?

\section{THEORETICAL BASIS}

The theory used in this study is a theory that originates in the conflict paradigm. This paradigm of conflict is rooted in Karl Marx's Theory. Where conflict is understood as an unavoidable phenomenon in the social reality of society. Conflict is not seen as having a negative connotation. But as a logical consequence of social life that is full of contradictions, the second Gramsci's Hegemony Theory and Social Movement Theory, Tom Bottomore defines social movements as a group sympathetic to certain social views that place themselves in daily political debates and are therefore ready to play a role and in activities such as demonstrations or "Ritous Assemblies"[4]. Tom Bottomore: 29) and Smelserian's Theory, Social Movements occur because of spontaneous statements or dissatisfaction with existing social structures, Election of Movement Leaders. Organizing, Confrontation and Achieving results have shown very significant things.

\section{RESEARCH METHODS}

This research uses descriptive, qualitative type, data collection using observation and in-depth interviews to obtain primary data. While secondary data in the form of information from print media, books, articles, and other documents. Overall data were analyzed qualitatively by including footage of the results of the interview. This is factual, which is straightforward and specific so that it becomes a kind of document that is able to speak for itself

\section{DISCUSSION}

Popular neoliberalism is spoken of in conservative ideology dubbed "Thatcherism" in Britain and "Reaganomics" in America. Neoliberal ideas become the foundation for the policies of institutions supporting global capitalism such as the WTO, IMF, World Bank, G7 countries and MNC (Multi National Corporation), the anatomy of global capitalism, in addition to being supported by international institutions, the system of global capitalism has special characteristics, namely: prometheen (giving priority to technology, new ideas), productivity (ideas are collected without limits), expansionist (collecting from unlimited accumulation) and the market system. Other features are exclusive rights and rivalry.

The previous version of this doctrine was called 'laissezfaire'. Now Americans are talking about neo-conservatism, Europeans are talking about liberalism, and French people are talking about 'la-pensee unique' (dominant or single way of thinking). using 'Neoliberalism', which recalls that the modern version of the doctrine shifted away from the version of the big 'liberal' political economists like Adam Smith or David Ricardo[5]

The post-war Keynesian model is based on a social welfare state and an industrial union with a foster father 
system and high salaries that have been formed by Democrats in the US and Social Democrats in Europe. The era of the 1980s was challenged by a new conservative ideology of hard money (monetarism) and free markets. Margaret Thatcher in the United Kingdom and Ronald Reagan in the US pushed for a restructuring of the Keynesian welfare state and created what was called the "Neo-liberalism" agenda. The neo-liberals argue that state intervention must be reduced, where market forces are given the freedom to solve all problems. Their model demands privatization and economic deregulation, drastic reductions in the social welfare budget, and political struggles to reduce the power of trade unions[6].

On the contrary in Indonesia, reforms in 1998 gave meaning not only to political change in Indonesia, but also to the birth of a new independent union. While students and other citizens struggle for political reform, workers struggle for better conditions, higher wages, and most importantly, the right to form independent trade unions or trade unions

The struggle for labor unions has taken various forms, from secret meetings to rallies, from strikes to political protests. After the fall of Soeharto in May 1998, the Indonesian government signed Convention 87 of the World Labor Organization (ILO), recognizing the right of workers to form independent unions, and the Minister of Manpower made a decree announcing that it would allow the establishment of an independent labor union.

\section{A. Profile of Trade Unions and Its Role in the Labor Movement}

\section{SARBUMUSI: Muslim Trade Union}

Some new unions are old unions that are trying to rebuild themselves after decades of repression. The Indonesian Muslim Trade Unions, better known as SARBUMUSI, represented an effort to revive the Muslim labor movement of the period before 1965. One of its leaders was a veteran trade union activist. Chairman of East Java DPW Sarbumusi H.Gordon, In 1967, he was a representative of trade union activists from an older generation issued by Suharto. Now he is back, working to rebuild SARBUMUSI. H.Gordon tells, about the emergence of history and the fall of Muslim unions. SARBUMUSI was established on September 27, 1954.

SARBUMUSI joined Nahdlatul Ulama (NU), which later became the Muslim Political Party

2. SBSI: From an underground movement to a formal legal movement

SBSI was established on April 25-1992, with the then Chairperson being Dr. Mochtar Pakpahan. One of the aims to support labor struggle in Indonesia is to get a decent wage in the regional minimum wage sector Mochtar Pakpahan's trade union model is inspired by European Social Democracy, especially trade unions that exist in capitalist societies such as in Western Europe and America, where trade unions tend to be bureaucratic, this can be seen with: First. The union "exists under a labor law system which means to institutionalize trade unions as part of the prevailing economic and political system. Second, make the union as an agent of mediation between workers and employers and seek a balance between workers and employers.

\section{SBR: Regional Trade Unions}

Regional Trade Unions (SBR), declared on May 1, 1998, coincide on International Labor Day (MayDay). SBR was declared in the middle of the current movement to undermine Suharto's New Order regime (ORBA). Stick to the principles: solidarity, democracy, social justice, equality and fairness of relations between women and men and anti-discrimination.

4. FNPBI: Making trade unions a political force

The management of FNPBI are former Student activists and some of the most advanced workers in terms of intellectuality and organizational activities. The permanent members of the FNPBI are members of the Democratic People's Union (PRD), Student Solidarity for Democracy (SMID) formed in 1991, the National Peasant Union (STN) formed in 1993 and the Indonesian Labor Struggle Center which was formed in 1994. These organizations were formed in the end they formed a democratic people's union in 1996 to become the Democratic People's Party. From the hands of PRD activists, FNPBI was formed.

\section{B. Trade Union Movements and Views on Neoliberalism}

The understanding of trade union activists regarding the existence of world economic institutions such as the IMF and World banks and the rules of the world economy are quite high. In one of the events commemorating International Labor Day (Mayday) in 2003, for example, several unions such as the Textile and Leather Workers Union in Indonesia, FNPBI, SBK, East Java Workers' Council, Regional Trade Unions and supported by several student elements such as LMND (League national student for Democracy) GMNI and FMN (National student front and NGO Foundation Arek Lintang Surabaya) in their call stating that the Government and the House of Representatives which passed the Manpower Act No. 13 of 2003, on 25 February 2003 was the result of an agreement with the ILO the international labor organization that was plotted with the Asian development bank (ADB), the IMF and the World bank and the WTO in making laborers merely objects of production and commodities.

This shows that there has been an awareness in the labor movement that domestic labor problems cannot be separated from various political economic decisions at the international level adopted and implemented by the national government as an extension of these foreign institutions and companies, following comments from labor activists about the international institution:

"The World Bank is an institution that is ready to help disburse funds for world capitalists, in this case America, to provide to third world countries including Indonesia by way of debt / or cool language soft loans / IMF, but in the eyes of our organization (FNPBI) see it as great catastrophe for the continued chaos of the Indonesian economy. If the repressed debtor does not want to abide by it, the IMF will not give him even a penny to pay off its debts. If the IMF does not provide loans, none of the 
imperialist governments or international financial institutions will provide money or write off old debts, in short the poor countries will surely experience total economic collapse! ... "(interview with Frans, Chair of FNPBI East Java)

"It's like a ghost that frightens workers now because none of their policies are in favor of the workers because with the free market the workers are not only dealing with employers/capital owners alike but there are more enemies of workers' comrades: the military, labor law in the eyes the workers are very detrimental to the position of the workers. There will be a composition between domestic workers and foreign workers where foreign workers are of a quality and ability to operate technology rather than domestic workers who only rely on labor (Interview with Suyitno, SBR Activist)

"It is very worrying because with the global economy all kinds of products will be sold freely throughout the world and freed from all duties/taxes and inevitable competition between giant capitalists and local capitalists in every country and the global nature of the economy today no longer accommodates humanity/conscience. Indonesia's economy will be destroyed First, Indonesia is a third world country that is currently in a developing stage so that the economic structure is not yet mature let alone ready to compete with European countries which on average are very mature economic structures. Second, it will affect the national output in each sector. Third: when it is forced, it is possible that many domestic companies will close down because they cannot compete.

There will be prolonged poverty due to the global economic impact because we know that the character of the world capitalists is very exploitative, let alone state intervention is very small or does not exist at all, because the state does not dare to guarantee protection of domestic production.

There will be more and more lines of unemployment due to layoffs because many companies are out of business because they are unable to compete with world giant companies that have greater capital and Indonesia's quality products are losing quality. There is no longer any guarantee from the state for the welfare of the workers. The purchasing power of workers is decreasing due to the very small wages/salaries... "(Interview with Suliyem, Secretary General of SBR).

Opinions about the existence of foreign institutions did not fully get a strong response from the existing trade unions in Surabaya. This is because not all trade unions choose to be vis a vis to the power of capital owners such as SBSI, which in their political struggle prefers to be cooperative towards the ruling regime and positions themselves as partners with capital owners and the government although it remains critical as expressed by the wrong one activist:

"World banks and the IMF and other foreign donor agencies are institutions that directly or indirectly are institutions that are heavily involved in the national planning and development process of our country. Their existence is detached by many other trade unionists considered as oppressive institutions with various strangling loans and policy packages that prioritize the interests of the owners of capital, especially foreign capital, but we must realize that without their presence it might be difficult for us to carry out development and advance economic sector. For example in the real sector without investors and foreign capital assistance, maybe the industry in our country will stall ... that's the problem, where will our workers work? And eat what? That's all, in my opinion, the issue of low wages is indeed very unfair and shows how their arrogance as the ruler, but we from SBSI will continue to negotiate and cooperate with capital owners and the government to pay more attention to the fate of workers ... " as said by Ilasiyani .SBSI

The State's role in the problems of Labor and employers in the Neoliberalism Policy

"Ready or not, free trade has become the world's choice. Caution should not be doubted ... (Former President Suharto at a speech in front of the Lemhanas course[7]. "Globalization is not a change that sweeps all world and cannot be stopped; globalization is a deliberate construction, at least in part"[8].

So far, globalization or in the language of the antiglobalization resistance movement is neoliberalism considered as a necessity and indeed desirable as a necessity. But globalization which is considered to unite the world community through shrinking time, space and loss of national borders is only an ideal. This is because the interconnectedness and various benefits expected from globalization do not occur; globalization then becomes a battleground between the strong, half strong and weak and the weakest.

In essence, the WTO, the IMF and the World Bank are regulative and administrative organs that defend the business interests of various transnational corporations (TNCs) and various international financial institutions, and ironically the neoliberalism policy which is much detrimental to the workers and people in general is actually agreed by many world leaders in a third country even a Soeharto who was so powerful and in power before his people was subject to submission before the interests of the neoliberalists.

The barbaric policies of Neoliberalism include 1 . Revocation of drinking water, food and electricity subsidies. 2. Application of repressive taxes 3. Evaluation of local currency 4. Drastic cuts in health and education budgets and policies are very detrimental to the small people. As a result the policy increased infant mortality and unemployment increased. Education and housing are getting worse because inflation is rampant, food commodity prices have jumped and real wages are falling. When the majority of small people are haunted by hunger, the rulers actually live in luxury and prosperity, escape the effects of cruel austerity programs, thanks to funding from the IMF and the World Bank[9].

If the people are desperate to make loud protests, the authorities immediately silence them with military and police repression. From the beginning the IMF and World Bank did tolerate a large budget for the armed forces. Following are comments from trade union activists regarding the role of the state and the state's support for the people, especially in the field of labor:

"It is no different from the New Order, why do I say it that way, because there is no significant change in the fate of the workers in the reform era and it can be proven that 
the Megawati / transition government work program is not a program designed to improve the welfare of the workers, for example there is no a product of labor law in favor of the workers actually impoverishes the workers

The state tries to escape responsibility when there are disputes between employers and workers and tends to side with employers with proven disputes that process is slow and does not seem to be serious in handling and solving problems and is always complicated ". (interview with Frans, chairman of FNPBI)

"We see the state only thinking about the process of economic recovery by inviting foreign investors to open jobs as an effort to overcome unemployment, the return is to make policies that facilitate" Capital Owners only "and ignore the interests of workers". If investment comes in only to overcome unemployment ... and moving the economy without thinking about "welfare" only provides "employment" this is very unfair ... the government should see "how laborers work ..." how they sweat their work with solid working hours, neglected rights and low wages!.. ". For us it is the same as selling the nation ...! Why are the ordinary people who are always sacrificed while those who enjoy the results of economic growth only the capital and bureaucrats support it ... "(interview with Suliyem, SBR secretary general)

At least since 1973 the protective role of the state as a protective labor has diminished, even today the state has become a party that suppresses workers' rights and interests. State intervention can be witnessed through legislation that facilitates the interests of capital owners, allowing police interference in reducing labor resistance. Even the Government and approved by the Indonesian Parliament passed three laws on labor, the Law on trade unions, the Law on PPHI and the Law on labor which generally do not reflect the political will to strengthen the position and improve labor conditions.

Even some time ago in several regions a "Tripartite agreement" was signed to attract investment and reduce the labor movement. The question is why is it not a "Tripartite agreement" that prohibits investors from closing their businesses and moving to other places or forbid investors to close their businesses and move to other places? Again, workers are positioned as parties who create investment discomfort and inconvenience.

"We see the government is still defending the interests of capital owners, if in the past the New Order with its militarism oppressed the labor movement both through a law that restricted labor rights both normatively and politically even with the repression of its military apparatus during the reformation era. However, the state still prioritized the interests of the owners capital ... for example, mas Law No. 13 of 2003 was enacted in the era of Megawati which was a democratically elected civilian government but still passed a law that was more pro to capital owners and besides that in the Megawati era workers whose demonstrations were still faced with police repression or with the masses the thugs are company ... so still the conditions don't change mas ... "(Interview with Suggestion, Chair of SBR)

From the facts above, the assumption that the role of the state in the era of globalization is getting weaker and is neutral is misleading. Multinational companies are basically not anti-state intervention, as long as the intervention is as much as possible for the sake of capital accumulation

\section{Trade Union Movements and Views Against Neoliberalism}

The trade union movement and view of Neoliberalism policy which is a variant of capitalism, can be seen from the background of the union both in terms of ideology and the movement that was built. In some trade union organizations that are used as objects of research such as Sarbumusi which is based on the majority of the workers' mass affiliated with the Mass Organization

Having the characteristics of a moderate movement that prioritizes compromise and lobbying employers or the government such as on normative issues such as demands for wage increases, enactment of contract labor and outsourcing, cuts in subsidies for basic necessities, even though there are still many injustices such as underperforming workers' wages or inhumane enforcement of contract labor and outsourcing legalized in the Manpower Act but Sarbumusi still expects to be able to do efforts to fight for the welfare of workers by lobbying the central and regional government as well as coordinating with employers' associations such as Apindo to formulate a labor policy such as determining a proper $\mathrm{KHM}$, as well as propose to amend the Labor Law which is deemed inhumane because it legalizes the contract labor and outsourcing system which is considered to endanger the continuity of labor work

While regarding these policy issues related to the global interests of international capitalists supported by state elites, Sarbumusi through the East Java DPP chairman felt that he did not have an analysis that led to issues of international political economy areas such as Neoliberalism policies so that responses to the effects of neoliberalism such as Privatization, and the interests of international institutions such as the IMF, World Bank, TNC and WTO as well as the state's position in the interests of Sarbumusi Neoliberalism cannot say much but in essence reject any form of oppression of workers in any way and in any policies.

SBSI as a moderate labor organization adopts the social democratic ideology as a "union that exists under a labor law system which means to institutionalize trade unions as part of the prevailing economic and political system and make the union a mediating agent between workers and employers and create a balance.

SBSI in responding to labor normative issues such as the issue of wages or legalization of contract labor and outsourcing in the labor law is more of a formal legal struggle by being involved in the drafting process of the law in parliament and providing legal advocacy for members involved in labor issues.

While the response to Neoliberalism policies, SBSI saw the role of donor institutions such as the IMF, World banks and the presence of Transnational Corporation companies very influential in national economic development and saw their positive role in moving the national economic sector 
even though it was recognized to benefit many foreign and state capital owners going forward, for that SBSI sees more importance in working with investors and the government in improving labor welfare.

SBK, SBR and FNPBI as trade unions whose ideology is Progressive Democratic Socialism, will obviously be in conflict with the class of capitalists supported by Neoliberalism policies related to the exploitative conflictual relations between the working class and financiers in the production process of the capitalist system. Although compromise solutions in Industrial disputes are not infrequently conducted by SBK, SBR and FNPBI.

Of course, with consideration as part of strategy and tactics, the views of SBK, SBR and FNPBI on their position as laborers and the position of employers as owners of the companies where they work are very far from the influence of these compromise values. The response of the three radical trade unions to normative issues such as low wages, legalization of contract labor and outsourcing in labor law, privatization of SOEs and others as well as cuts in subsidies for basic necessities are forms of exploitation by capital owners and are a direct impact felt by workers and small people. the other is from Neoliberalism policies which intensify efficiency in the production process and create a flexible labor market so that if workers are not needed at any time, they can be laid off.

They strongly oppose these policies and actively oppose them through demonstrations both in the company and in state institutions. The response to the role of the IMF, World Bank, WTO and TNC within the Neoliberalime policy framework was strongly opposed by these radical trade unions because their existence was no more in the context of carrying out new forms of colonialism either through loans that strangled the people or urging economic policies that did not benefit the state the third world and positions laborers no more as exploitative commodities in an increasingly competitive production process

Trade Unions and Views on neoliberalism policies are not only based on the realities on the ground but are also the result of a fairly in-depth analysis based on the literature they get from news or writings on the state of the labor movement in other countries dealing with similar policies such as the movement workers in Latin America, South Korea and mass actions that took place in Seattle in 1999, besides the results of discussions with trade unions from other countries who came to Indonesia[10].

Information Progress is implemented by trade unions in every opportunity of action both local and normative issues or national demonstrations such as the Mayday celebration. Issues such as the rejection of the IMF and World Bank and accusations of government policies that are considered to only serve the interests of capital often carried alongside issues such as wage increases and other welfare improvements.

\section{CONCLUSION}

The emergence of the spirit of Multiunionism or building trade unions in the reform era until now helps improve and build bargaining positions of labor against the policy of the capital owner or the company and the government. The awareness of trade unions in responding to various Government policies considered to reflect the interests of Neoliberalism is quite high.

Trade Unions take part in joint agreements built with other community groups that have the same awareness as Student activists, academics, NGOs, peasant activists, women activists and so on are expected to be able to build bargaining positions or 'War of Position' conditions in Gramsci against the dominant discourse and system of Neoliberalism supported by international institutions

It is indeed not easy but the emergence of labor awareness about the negative impact of Neoliberalism is a step forward than the image of the previous labor movement which only moves at the level of normative issues that do not touch the main problem namely injustice in the economic system - the prevailing politics.

\section{REFERENCES}

[1] Chris Harman, "Anti-capitalism: Theory and Practice.” London, 2000.

[2] C. Husain Pontoh, Akhir Globalisasi. Jakarta: CBOOKS, 2003.

[3] Jawa Pos, “Jawa Pos," Jawa Pos, Surabaya, p. 5, 02-May-2003.

[4] T. Bottomore, Sosiologi Politik. Jakart: Rineka Cipta, 1992.

[5] S. George, Republik pasar bebas, menjual Kekuasaan Negara Demokrasi dan civil Society kepada kapitalisme Global. Jakarta: Bina Rena Pariwara, 2002.

[6] D. Labotz, Made In Indonesia, Indonesian Workers since Soeharto. Cambridge: South End Press, 2001.

[7] Kompas, "Kompas," Kompas, Jakarta, p. 12, 14Dec-1994.

[8] Rubens Ricupero, "The Xth Session in Bangkok, February, 2000," Bangkok.

[9] Sony Karsono, "“International Capitalism of Actors and Strategies," vol. 5, 2000.

[10] Labor Appeal, "Labor Appeal," 9th Edition, Jun2000 . 